\title{
CHEMICAL MODIFICATION OF BARLEY MALT $\alpha$-AMYLASE 2: INVOLVEMENT OF TRYPTOPHAN AND TYROSINE RESIDUES IN ENZYME ACTIVITY
}

\author{
by \\ RICHARD M. GIBSON and BIRTE SVENSSON \\ Department of Chemistry, Carlsberg Laboratory, \\ Gamle Carlsberg Vej 10, DK-2500 Copenhagen Valby
}

\begin{abstract}
Keywords: N-bromosuccinimide, tetranitromethane, acarbose, aplanin, dimethyl(2-hydroxy-5-nitrobenzyl)sulphonium bromide, difference spectroscopy, fluorescence spectroscopy, sulphydryl reactivity
\end{abstract}

\begin{abstract}
Barley malt $\alpha$-amylase 2 has been purified on a large scale and the resulting enzyme preparation used in various chemical modification experiments. Results from tryptophan and tyrosine specific modifying reagents, as well as difference and fluorescence spectroscopy techniques, which studied the interaction of a variety of ligands, indicate that tryptophanyl and tyrosyl residues are involved in enzyme activity. Of the 16 tryptophanyl residues present in the enzyme, 4 could be modified using dimethyl(2-hydroxy-5-nitrobenzyl)sulphonium bromide. This caused inactivation of the enzyme. Addition of the inhibitor aplanin, a pseudo-maltooligosaccharide, decreased the loss of enzyme activity and protected 2 tryptophanyl residues from modification. Aplanin also protected the enzyme from inactivation by tetranitromethane, a tyrosine specific reagent.

$\beta$-Cycloheptaamylose appears to interact with a tryptophanyl residue not essential for enzyme activity, suggesting that this residue may be located in a second ligand binding site on the enzyme. This is in agreement with previous predictions of a "surface" site on barley malt $\alpha$-amylase.
\end{abstract}

\section{INTRODUCTION}

$\alpha$-Amylase (1,4- $\alpha$-glucan glucanohydrolase, EC 3.2.1.1) plays a crucial role in starch degradation in cereal endosperms. In barley two groups of isozymes, $\alpha$-amylase 1 and 2 , are produced by the aleurone cells during germination $(5,7)$. $\alpha$-Amylase 2 is the dominant group and consists of molecular forms representing a range of higher isoelectric points $(\mathrm{pl}=5.8-6.6)$ compared to the lower values $(\mathrm{pl}=4.5-5.2)$ characteristic of the group 1 isozymes (19). The two groups are also distinguished by their sensitivity to thiols, low $\mathrm{pH}$ values and elevated temperatures $(2,3$, $20,25)$. Furthermore, $a$-amylase 1 is more efficient at degrading starch granules than $\alpha$-amylase 2 reflecting, perhaps, different physiological roles for the isozymes $(26,46)$. Recently complete primary structures, deduced from cDNA sequences, were reported for an $\alpha$-amylase 1 and an $\alpha$-amylase 2 , showing $78 \%$ amino acid se-

Abbreviations: DTNB = 5.5'-dithiobis(2-nitrobenzoic acid); HNB = dimethyl(2-hydroxy-5-nitrobenzyl)sulphonium bromide; MES $=2(\mathrm{~N}$-morpholino)ethanesulphonic acid; NBS $=\mathrm{N}$-bromosuccinimide; $\mathrm{TNM}=$ tetranitromethane. 
quence homology $(6,35,36)$ and the $\alpha$-amylases prepared in this laboratory conform to these sequences (42).

Limited knowledge exists about the relationship between structure and function for cereal $\alpha$-amylases. However, some information can possibly be deduced by comparison with structures of better characterized amylases. X-ray crystallographic studies of Taka-amylase A suggest that aspartic and glutamic acid residues catalyse the hydrolysis of glucosidic bonds, while histidyl. tyrosyl and tryptophanyl residues participate in binding of the glucose residues of the substrate to various subsites in the active site (28). Chemical modifications and spectroscopy support these findings $(18,21,22)$. Similar residues have also been found at or near the active centre of $B$. amyloliquefaciens $\alpha$-amylase $(9,10,23)$. Further evidence that tryptophanyl residues play an important role in substrate binding comes from investigations on glucoamylases from $A$. niger and $R$. niveus $(8,32)$, chicken pancreas $\alpha$-amylase (4), and soybean $\beta$-amylase (30).

A number of starch and glycogen converting enzymes have been reported to possess an additional sugar binding site, sometimes called a surface site, at a distance from the active site region. Such sites have been demonstrated in porcine pancreatic $\alpha$-amylase by ligand binding (24), x-ray crystallography $(14,33)$ and kinetic studies $(34,38)$, in glycogen phosphorylase by $x$-ray crystallography $(11,37)$, in glucoamylases by adsorption to starch granules $(41,44)$, and in barley $\alpha$-amylase by mathematical analysis of the distribution of products from digestion of amylose (27). In the latter enzyme it has been suggested that the surface site is responsible for the binding of $\beta$-cycloheptaamylose and this has been utilized in affinity chromatography of the enzyme $(39,45,46)$. The $\beta$-cycloheptaamylose does not appear to inhibit gelatinized starch hydrolysis by cereal $\alpha$-amylases but it does reduce both the binding of $\alpha$-amylase to starch granules and the release of soluble starch from such granules (46).

The present study involving barley malt $\alpha$ amylase 2 has investigated ligand binding and the role of tryptophan and tyrosine residues in activity by means of specific chemical modifica- tion and spectroscopy. Evidence for the existence of two sugar binding sites, one located inside and the other outside of the active site area, is obtained from the reactivity and accessibility of aromatic residues in various ligand enzyme complexes. In addition, a large scale purification procedure resulting in the isolation of $100-200 \mathrm{mg}$ of $\alpha$-amylase 2 is described.

\section{MATERIALS AND METHODS}

\subsection{Materials}

Barley malt (Hordeum vulgare L., cv. Triumph) (kilning regime: $20-55^{\circ} \mathrm{C}, 2 \mathrm{~h} ; 55-85^{\circ} \mathrm{C}$, $\left.8 \mathrm{~h} ; 85^{\circ} \mathrm{C}, 1.5 \mathrm{~h}\right)$ was obtained from the Carlsberg Malting Plant, Copenhagen. The malt was milled in a disk mill before use as the starting material for enzyme purification.

Epoxy-Sepharose 4B, Isoelectric Focusing Calibration Kit ( $\mathrm{pH} \mathrm{3-10)}$ and Phadebas blue starch tablets were from Pharmacia Fine Chemicals, Uppsala, Sweden. Sigma Chemical Co., St. Louis, MO supplied $\beta$-cycloheptaamylose, dimethyl(2-hydroxy-5-nitrobenzyl) sulphonium bromide, maltotriose, and MES. N-Bromosuccinimide (recrystallized from water before use) and tetranitromethane were from Fluka, Buchs, Switzerland. Maltose monohydrate and Fractogel CM $650(\mathrm{M})$ were supplied by Merck, Darmstadt, FRG and Ampholine PAGplates, pH 3.0-9.0, were from L.K.B., Bromma, Sweden.

Acarbose (BAYg5421) and aplanin (BAYe4609) were the kind gift of Drs. E. TRusCHEIT and D. SCHMIDT, Bayer AG, Wuppertal, F.R.G. who also provided the information that the aplanin preparation contained approx. 20\% pseudo-oligosaccharides of the acarbose type, which inhibit $\alpha$-amylase (see Figure 2), and $80 \%$ non-inhibitory oligosaccharides.

\subsection{Methods}

\subsubsection{Purification of $\alpha$-amylase 2 from barley malt}

Extraction and purification of $\alpha$-amylase 2 from kilned barley malt was carried out using an improved large scale version of the procedure previously reported (42). $10 \mathrm{~kg}$ of malt flour was extracted in 801 distilled $\mathrm{H}_{2} \mathrm{O}, \mathrm{pH} 4.9$, and 1 
$\mathrm{mm}-\mathrm{CaCl}_{2}$, for $12 \mathrm{~h}$ at $20{ }^{\circ} \mathrm{C}$ the resulting suspension was filtered and the extract liquor concentrated to approximately 101 . Ammonium sulphate was added to the concentrate to $20 \%$ saturation, the resulting sediment was discarded and the supernatant was then taken to $60 \%$ saturation with ammonium sulphate. The precipitate obtained was isolated by centrifugation and either used as starting material for purification of the enzyme or frozen at $-15^{\circ} \mathrm{C}$ until required.

The ammonium sulphate precipitate was redissolved in $20 \mathrm{~mm}$-sodium acetate, $\mathrm{pH} 5.5$, containing $1 \mathrm{~mm}-\mathrm{CaCl}_{2}$, applied to a flat bed column $(10 \times 3 \mathrm{~cm})$ of $\beta$-cycloheptaamyloseSepharose 4B affinity gel and then eluted with the equilibration buffer containing $\beta$-cycloheptaamylose $(8 \mathrm{mg} / \mathrm{ml})(39)$ at a flow rate of ca. 100 $\mathrm{ml} / \mathrm{min}$. Fractions containing $\alpha$-amylase activity were pooled and, after $\mathrm{pH}$ and ionic strength adjustment, subjected to ion-exchange chromatography on Fractogel CM $650(\mathrm{M})$ equilibrated with $20 \mathrm{~mm}$-sodium acetate, $\mathrm{pH} 4.5$, and $1 \mathrm{mM}-\mathrm{CaCl}_{2}, \alpha$-Amylase was eluted by applying a linear gradient from the equilibration buffer to $20 \mathrm{~mm}$-sodium acetate, $200 \mathrm{~mm}-\mathrm{NaCl}$ and 1 $\mathrm{mm}-\mathrm{CaCl}_{2}, \mathrm{pH}$ 5.5. Fractions containing $\alpha$-amylase 2 were pooled, adjusted to $\mathrm{pH} \mathrm{6.7,} \mathrm{and} \mathrm{taken}$ to $60 \%$ saturation with ammonium sulphate. The pelleted enzyme was stored in aliquots at $-15^{\circ} \mathrm{C}$ until redissolution in buffer, the $\mathrm{pH}$ of which should exceed 6 to avoid precipitation of the enzyme from solution.

\subsubsection{Analytical procedures}

Enzyme activity was determined using Phadebas blue starch tablets as per suppliers' instructions. One unit of activity is the amount of enzyme required to produce a change of 1 O.D. unit at $620 \mathrm{~nm}$ during $15 \mathrm{~min}$ incubation at 37 ${ }^{\circ} \mathrm{C}$, pH 7.0. Concentrations of $\alpha$-amylase were determined spectrophotometrically $\left(\mathrm{E}^{1 \%}=24\right.$, determined from amino acid analysis and absorbancy measurements at $280 \mathrm{~nm}$ ) or by amino acid analysis as previously described (42). Isoelectric focusing was carried out according to the manufacturers' instructions (47).

\subsubsection{Chemical modifications}

Oxidation of $\alpha$-amylase with $\mathrm{N}$-bromosuccinimide (NBS) was carried out essentially as reported earlier (8) with the modifications described in section 3.4. All solutions were dialyzed against reaction buffer and filtered through a Millipore filter $(0.45 \mu \mathrm{m})$ prior to use. The number of modified tryptophanyl residues was calculated as described by SPANDE and WITKOP (40).

Chemical modification with the Koshland reagent, dimethyl(2-hydroxy-5-nitrobenzyl)sulphonium bromide (HNB) was performed by the method of HORTON and TUCKER (17). Reagent, freshly prepared in distilled water, was added to protein solutions in $10 \mathrm{~mm}$-MES, 1 $\mathrm{mM}-\mathrm{CaCl}_{2}, \mathrm{pH} 6.7$, in ratios of up to 200 -fold molar excess. This $\mathrm{pH}$ value was necessary to prevent precipitation of the enzyme which occurs at the lower $\mathrm{pH}$ optimal for this modification of tryptophan (17). The reaction mixtures were incubated at room temperature for $20 \mathrm{~min}$ after which time HNB-hydroxide was removed by centrifugation in an Eppendorf bench top centrifuge. Excess reagent was subsequently removed by exhaustive dialysis involving several changes of distilled water. An aliquot of the dialysed sample was adjusted to $\mathrm{pH} 10-11$ with conc. $\mathrm{NaOH}$ and the number of modified tryptophans measured spectrophotometrically at $410 \mathrm{~nm}$ using an extinction coefficient of 18,400 $\mathrm{M}^{-1} \cdot \mathrm{cm}^{-1}$ for the modified groups (17).

Nitration of the enzyme was carried out with tetranitromethane (TNM) in $100 \mathrm{~mm}$-potassium phosphate $1 \mathrm{~mm}-\mathrm{CaCl}_{2}, \mathrm{pH} 7.5$ as described by GLAZER (12). The reaction was stopped by addition of 2-mercaptoethanol followed by dialysis vs. $1 \% \mathrm{NH}_{4} \mathrm{HCO}_{3}$ solution. Iodination of barley malt $\alpha$-amylase 2 was achieved by the method of AZARI and FEENEY (1). A solution of iodine ( $4 \mathrm{~mm}$ ) in potassium iodide ( $480 \mathrm{~mm}$ ) was added to a solution of the enzyme to the required molar excess.

\subsubsection{Determination of free sulphydryl groups}

Protein sulphydryl groups were determined in the native and denatured enzyme by the method of HABEEB (13). Native enzyme $(32 \mu \mathrm{M})$ in $1 \mathrm{ml}$ $100 \mathrm{~mm}$-sodium phosphate, $\mathrm{pH} 8$, were added to 
$50 \mu \mathrm{l}$ of $10 \mathrm{~mm}$-DTNB solution. The absorption at $412 \mathrm{~nm}$ was measured at various times and the number of modified sulphydryl groups determined by use of a molar absorptivity value of $13,600 \mathrm{M}^{-1} \cdot \mathrm{cm}^{-1}(13)$.

\subsubsection{Difference absorption spectra}

Difference absorption spectra were obtained on Cary model 219 or Varian model 2200 spectrophotometers as previously described (8).

\subsubsection{Estimation of the number of exposed tryptophan and tyrosine residues}

The number of tryptophanyl and tyrosyl residues exposed to the solvent were estimated by the method of HERSKOVITS and SORENSEN (16). Ethylene glycol and dimethyl sulphoxide were employed as perturbants. The $\Delta \varepsilon$ values of $\alpha$-amylase at 292 and $284 \mathrm{~nm}$ were measured at a perturbant concentration of $20 \%$ (31). The number of tryptophanyl and tyrosyl residues accessible to the solvent were then estimated using the following equations:

$$
\begin{aligned}
& \mathrm{a} \cong \frac{\Delta \varepsilon \text { (a-amylase }) 291-293}{\Delta \varepsilon(\operatorname{Trp}) 291-293} \\
& \mathrm{~b} \cong \frac{\Delta \varepsilon \text { (a-amylase) } 283-286^{-\mathrm{a} \cdot \Delta \varepsilon(\text { Trp })} 283-286}{\Delta \varepsilon(\text { Tyr }) 283-286}
\end{aligned}
$$

where $\mathbf{a}$ and $\mathbf{b}$ are the number of tryptophanyl and tyrosyl residues, respectively, which are accessible to the perturbant, $\Delta \varepsilon$ ( $\alpha$-amylase) is the difference molar absorption coefficient of the enzyme in the solvent (20\%) and $\Delta \varepsilon$ (Trp) and $\Delta \varepsilon(T y r)$ are the difference molar absorption coefficient values of the model compounds AcTrp-OEt and Ac-Tyr-OEt, in the solvent (20\%) (16).

\subsubsection{Fluorescence spectra}

An Aminco model SPF 500 spectrofluorometer was used for fluorescence measurements. Small increments $(10 \mu \mathrm{l})$ of ligand were added to an enzyme solution $(1 \mathrm{ml})$. The resulting fluorescence intensity was measured and corrected for the effect of dilution. The percentage difference in fluorescence intensity $(\Delta \mathrm{F} \%)$ relative to the fluorescence intensity of the original solution was expressed according to the formula:

$$
\Delta F \%=\frac{F_{i}-F_{f}}{F_{i}} \times 100 \%
$$

where $F_{1}$ and $F_{f}$ are the initial and final fluorescence intensities, respectively.

\section{RESULTS}

\subsection{Purification of $\alpha$-amylase 2}

Table I shows the relative yields of $\alpha$-amylase 2 obtained (section 2.2.1). By this method 100$200 \mathrm{mg}$ of $\alpha$-amylase 2 can be obtained from 10 $\mathrm{kg}$ of barley malt. Figure 1 shows a typical IEF pattern of the purified product.

The increase in the total amount of $\alpha$-amylase

\begin{tabular}{|c|c|c|c|c|}
\hline & $\operatorname{Vol}(\mathrm{ml})$ & $\begin{array}{l}\text { Total units } \\
\left(\times 10^{6}\right)\end{array}$ & $\mathrm{E}_{280} / \mathrm{ml}$ & Units $/ \mathrm{E}_{280}$ \\
\hline Concentrated crude extract & 10,000 & 1.48 & 47 & 3 \\
\hline $\begin{array}{l}\text { Resuspended } 20-60 \% \\
\text { ammonium sulphate fraction }\end{array}$ & 3,000 & 1.10 & 22 & 17 \\
\hline $\begin{array}{l}\text { Eluate from } \beta \text {-cycloheptaamyl } \\
\text { Sepharose } 4 B\end{array}$ & 1,800 & 2.35 & 1.5 & 870 \\
\hline $\begin{array}{l}\text { Eluate of } \alpha \text {-amylase } 2 \\
\text { from Fractogel CM } 650(\mathrm{M})\end{array}$ & 450 & 0.66 & 1.5 & 1,020 \\
\hline
\end{tabular}
activity following purification on the affinity

Table I. Purification of barley malt $a$-amylase 2 


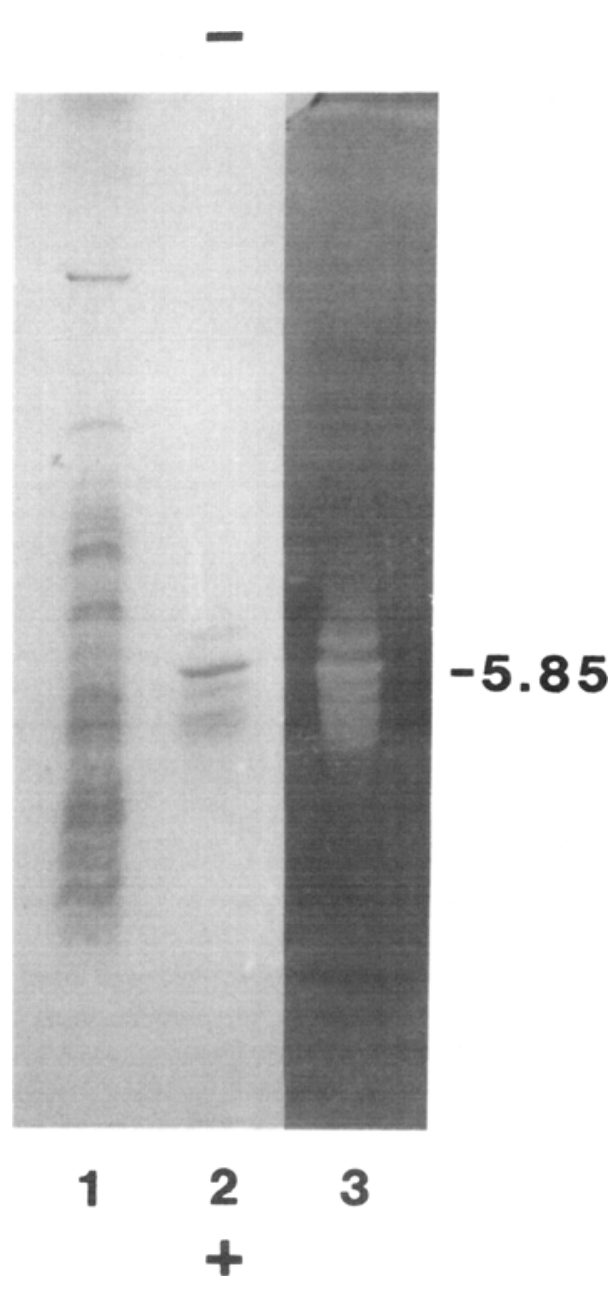

Figure 1. Isoelectric focusing of barley malt $\alpha$-amylase 2 on Ampholine PAGplates, pH 3.0-9.0. Approximately $10 \mu \mathrm{g}$ of the purified amylase, following chromatography on Fractogel CM $650(\mathrm{M})$, was applied to lane 2. Lane 1 contains a crude mixture of extracted barley malt proteins (ca. $50 \mu \mathrm{g}$ ). Lane 3 shows the activity of starch hydrolysing enzymes in the purified preparation (ca. $2.5 \mu \mathrm{g}$ ) developed using an iodine/potassium iodide stain.

column has been noted in several different preparations. This is most likely due to removal of the barley amylase/subtilisin inhibitor (BASI) (29) from the enzyme during this purification step. The kilning caused inactivation of the majority of $\alpha$-amylase 1 , hence the purification procedure produced only the high pI group, $\alpha$-amylase 2 .

\subsection{Solvent perturbation of $\alpha$-amylase 2}

The number of tryptophanyl and tyrosyl residues accessible to the solvent was estimated as described in section 2.2.6. In $\alpha$-amylase 2, 4 tryptophans from a total of 16 and 10 tyrosines from a total of 15 were perturbed by the solvent dimethyl sulphoxide. When ethylene glycol was employed as perturbant the number of residues accessible were found to be 6 and 12 for tryptophan and tyrosine, respectively.

\subsection{Evidence for the involvement of tryptophan and tyrosine in barley $\alpha$-amylase 2 activity}

Inactivation of barley $\alpha$-amylase 2 could be achieved by incubation of the enzyme with either the tryptophan specific reagents, Nbromosuccinimide (NBS), and dimethyl(2hydroxy-5-nitrobenzyl)sulphonium bromide (HNB), or the tyrosine specific reagents, tetranitromethane (TNM) and iodine/potassium iodide. The results are summarised in Table II.

\subsection{Oxidation of $\alpha$-amylase 2 by NBS in the presence of ligands}

The enzyme was treated with NBS in the presence of various $\alpha$-amylase specific ligands. These included maltose, acarbose, $\beta$-cycloheptaamylose and aplanin. $\beta$-Cycloheptaamylose does not inhibit cereal $\alpha$-amylase activity towards gelatinized starch (46) but binds to a so called "surface site" outside the active site region (45). Acarbose and aplanin are pseudo-oligosaccharides with the general structure shown in Figure 2. Aplanin is a more potent inhibitor of $\alpha$-amylase activity than acarbose (data not shown) and has a lower dissociation constant (see section 3.9).

Oxidation of tryptophanyl residues in barley malt $\alpha$-amylase 2 at room temperature in 50 mM-sodium acetate, $\mathrm{pH}$ 5.0, caused rapid precipitation of the protein. This precipitation could be subsiantially reduced by carrying out the oxidation at $4^{\circ} \mathrm{C}$ in $50 \mathrm{~mm}-\mathrm{MES}, \mathrm{pH} 6.7$, half-saturated in $\mathrm{CaSO}_{4}$. However, the enzyme 
Table II. The effect of tryptophan and tyrosine modifying reagents on $\alpha$-amylase 2.

\begin{tabular}{|c|c|c|c|c|c|c|c|}
\hline \multicolumn{2}{|c|}{ a) N-Bromosuccinimide } & \multicolumn{4}{|c|}{$\begin{array}{l}\text { b) Dimethyl(2-hydroxy-5-c) Tetranitromethane } \\
\text { nitrobenzyl)sulphonium } \\
\text { bromide }\end{array}$} & \multicolumn{2}{|c|}{$\begin{array}{l}\text { d) Iodine/potassium } \\
\text { iodide }\end{array}$} \\
\hline $\begin{array}{c}\text { Molar excess } \\
\text { of reagent }\end{array}$ & $\begin{array}{l}\text { Activity } \\
\text { remaining(\%) }\end{array}$ & $\begin{array}{l}\text { Molar excess } \\
\text { of reagent }\end{array}$ & $\begin{array}{l}\text { Activity } \\
\text { remaining(\%) }\end{array}$ & $\begin{array}{c}\text { Molar excess } \\
\text { of reagent }\end{array}$ & $\begin{array}{l}\text { Activity } \\
\text { remaining(\%) }\end{array}$ & $\begin{array}{l}\text { Molar excess } \\
\text { of reagent }\end{array}$ & $\begin{array}{l}\text { Activity } \\
\text { remaining(\%) }\end{array}$ \\
\hline 0 & 100 & 0 & 100 & 0 & 100 & 0 & 100 \\
\hline 6.3 & 100 & 20 & 31 & 10 & 38 & 0.6 & 100 \\
\hline 13 & 65 & 50 & 10 & 20 & 19 & 1.8 & 41 \\
\hline 19 & 13 & 100 & 2.6 & 40 & 0 & 3.0 & 32 \\
\hline \multirow[t]{2}{*}{25} & 6.8 & 200 & 0 & & & 12 & 2 \\
\hline & & & & & & 30 & 0 \\
\hline
\end{tabular}

$\alpha$-Amylase 2 was incubated with the molar excess of the reagents indicated above (see 2.2.3). a) NBS: $1 \mathrm{ml}$ of enzyme solution $(4.8 \mu \mathrm{M})$ in $50 \mathrm{~mm}$-MES and half-saturated $\mathrm{CaSO}_{4}, \mathrm{pH} 6.7$ was treated with aliquots of $10 \mathrm{~mm}-\mathrm{NBS}$. The solution was mixed and incubated at room temperature for 2 min before assaying. b) Enzyme (32 $\mu \mathrm{M})$ in $400 \mu \mathrm{l}$ $10 \mathrm{~mm}$-MES, $1 \mathrm{mM}^{-\mathrm{CaCl}_{2}}$, pH 6.7 was incubated at room temperature with dimethyl(2-hydroxy-5-nitrobenzyl)sulphonium bromide. c) stock solution of TNM $(650 \mathrm{mM})$ was added to a solution containing enzyme $(16 \mu \mathrm{M})$ to give the required molar excess. Final volume of reaction mixture was $400 \mu \mathrm{l}$ and all solutions were prepared in $100 \mathrm{~mm}$-potassium phosphate, $1 \mathrm{~mm}-\mathrm{CaCl}_{2}, \mathrm{pH} 7.5$. The solution was incubated at room temperature for $60 \mathrm{~min}$ before assaying. d) A solution of iodine $(4 \mathrm{mM})$ in potassium iodide $(480 \mathrm{mM})$ was added to the enzyme $(33 \mu \mathrm{M})$ in $100 \mathrm{~mm}$-potassium phosphate, $\mathrm{pH} 7.5$, to a total volume of $200 \mu \mathrm{l}$. This solution was incubated for $20 \mathrm{~min}$ and then assayed.

was still apt to precipitate as the NBS concentration was increased, but it was noticed that addition of ligands reduced this tendency.

Figure 3 gives the results obtained with several ligands used in an attempt to protect the enzyme from oxidation by NBS. The uncomplexed enzyme loses activity rapidly with increasing NBS concentration whereas both maltose+ acarbose and maltose+acarbose $+\beta$-cycloheptaamylose protect the activity considerably. However, only aplanin (Figure 3 ) affords essentially complete protection of the activity while $\beta$-cycloheptaamylose alone (data not shown) did not prevent inactivation. Both aplanin and the

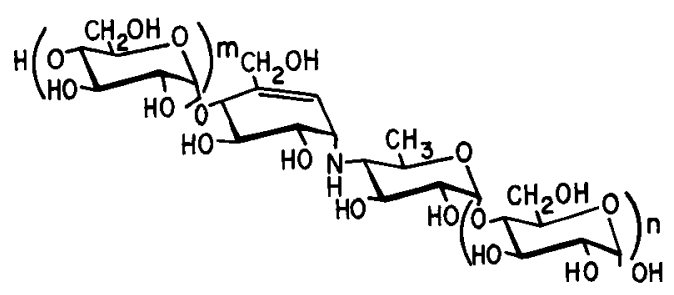

Figure 2. Structure of the pseudo-oligosaccharides acarbose and aplanin. Acarbose (BAYg5421) $\mathrm{m}=0, \mathrm{n}=2$; aplanin (BAYe4609) $\mathrm{m}+\mathrm{n}=5-10$. mixture of maltose+acarbose $+\beta$-cycloheptaamylose hinder oxidation of approximately one tryptophanyl residue when compared to maltose+acarbose which provides only a minor protection of tryptophan relative to the ligand free reaction conditions. Since aplanin protects activity and $\beta$-cycloheptaamylose does not, the tryptophan(s) protected by these ligands are either not the same or aplanin, in addition, prevents modification of tyrosyl or other residues which are susceptible to NBS (40) and which are essential for the enzymic activity. Amino acid analysis of the unprotected enzyme following oxidation by NBS indicates that as many as 5 tyrosyl residues are lost during the modification (data not shown). That tyrosyl residues are indeed essential for activity is suggested by the inactivation of the enzyme by TNM and $\mathrm{I}_{2} / \mathrm{KI}$ treatment (Table II). Following NBS oxidation to complete inactivation only 1.2 sulphydryl groups were free to react with DTNB compared to 2.6 in the unoxidized enzyme. This suggests that, in addition to tryptophanyl and tyrosyl residues being lost during oxidation by NBS, sulphydryl groups are also oxidized (see section 3.7 ). 


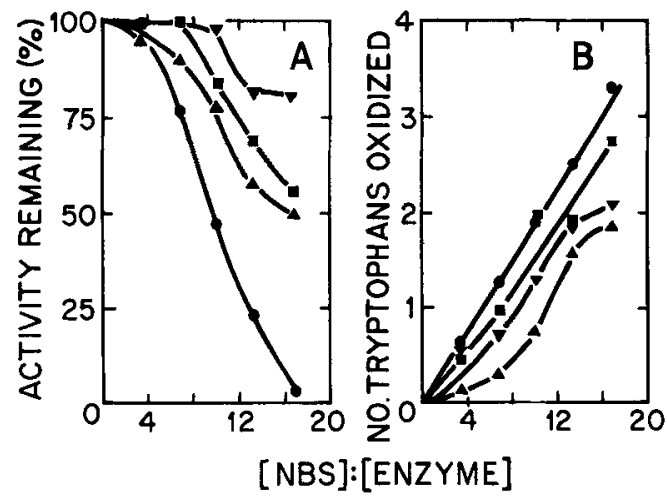

Figure 3. Effect of increasing NBS concentration on the activity and the number of tryptophanyl residues oxidized in $\alpha$-amylase 2 in the presence of various ligands. Enzyme (15 $\mu \mathrm{M})$ was incubated with increasing amounts of NBS at $4{ }^{\circ} \mathrm{C}$ in $50 \mathrm{~mm}$-MES and half-saturated $\mathrm{CaSO}_{4}, \mathrm{pH} 6.7$, in the absence (๑) and presence of the following ligands: maltose $(0.42 \mathrm{M})+$ acarbose $(3.0 \mathrm{mM})(\mathbf{\square})$; maltose $(0.42 \mathrm{M})+$ acarbose $(3.0 \mathrm{~mm})+\beta$-cycloheptaamylose $(8.8 \mathrm{mM})(\Delta)$; aplanin $(10 \mathrm{mg} / \mathrm{ml})(\boldsymbol{\nabla})$. A. activity profile, B. effect of oxidation on tryptophan.

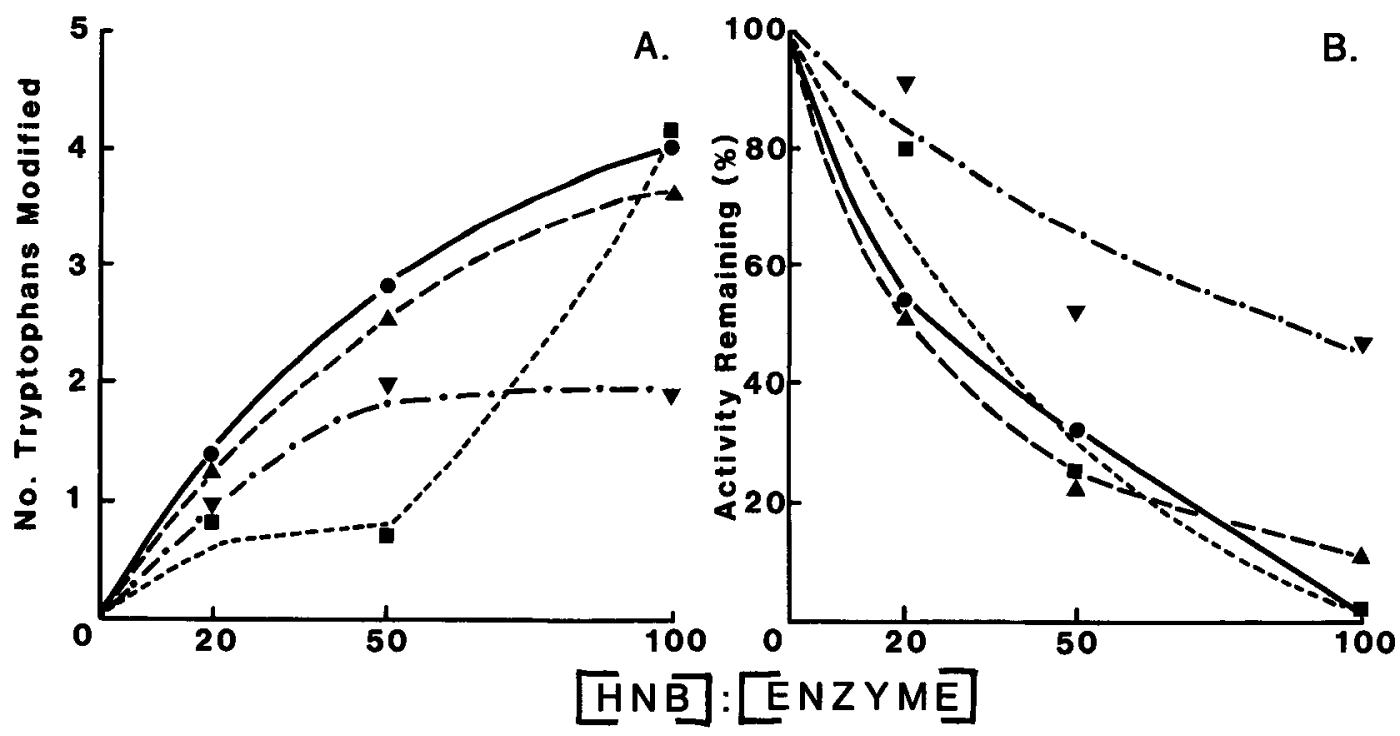

\subsection{Chemical modification with HNB}

Inactivation of barley malt $\alpha$-amylase 2 with HNB did not result in precipitation of the protein. Figure 4 shows the effect of increasing reagent concentrations on the enzyme activity and the extent of modification in the presence of the different ligands. Aplanin is found to reduce the extent of inactivation to $50 \%$ of the original activity and to protect tryptophanyl residues from modification. Thus, at a high molar excess of reagent, 4 tryptophanyl residues are modified with complete loss of activity in the uncomplexed enzyme whereas only 2 are modified in the presence of aplanin. In a similar manner to the NBS experiments $\beta$-cycloheptaamylose prevents tryptophan modification at the lower molar excesses of reagent, but this effect is lost at the highest concentration of HNB, where 4 tryptophanyl residues are modified. In contrast to aplanin $\beta$-cycloheptaamylose affords no protection of the activity, suggesting that a tryptophanyl residue essential for activity is not protected by this ligand. The presence of acarbose during HNB treatment has no effect on either the number of tryptophans modified or

Figure 4. Modification of $\alpha$-amylase 2 with dimethyl(2-hydroxy-5-nitrobenzyl)sulphonium bromide. Enzyme (35 $\mu \mathrm{M}$ ) was incubated with several concentrations HNB at room temperature for $1 \mathrm{hr}$, in the absence $(-)$ and presence of the following ligands: acarbose $(3.0 \mathrm{~mm}) \mathbf{\Delta - \Delta}$; aplanin $(10 \mathrm{mg} / \mathrm{ml}) \nabla \bullet-\nabla ; \beta$-cycloheptaamylose $(8.8$

---a. A. number of tryptophans modified, B. activity profile. 
Table III. Modification of $\alpha$-amylase 2 with tetranitromethane.

\begin{tabular}{lccc}
\hline & TNM & $\begin{array}{c}\text { Activity } \\
\text { remaining(\%) }\end{array}$ & $\begin{array}{c}\text { Number of tyrosyl } \\
\text { residues modified }\end{array}$ \\
Uncomplexed enzyme & - & 100 & 0 \\
Uncomplexed enzyme & + & 4.1 & 4 \\
Aplanin & + & 85 & 1 \\
Acarbose & + & 2.7 & 3 \\
Maltose & + & 7.6 & 4 \\
$\beta$-Cycloheptaamylose & + & 8.0 & 3 \\
Maltose+acarbose & + & 14 & 3 \\
Maltose+acarbose+ $\beta$-cycloheptaamylose & + & 24 & 3 \\
\hline
\end{tabular}

Barley malt $\alpha$-amylase $2(30 \mu \mathrm{M})$ was treated with $1 \mathrm{mM}$-tetranitromethane, in the presence of various ligands, for $1 \mathrm{~h}$ at room temperature (2.2.3). The concentration of the ligands in the reaction mixtures was as follows: acarbose $(3 \mathrm{mM})$; maltose $(0.42 \mathrm{M}) ; \beta$-cycloheptaamylose $(8.8 \mathrm{mM})$; aplanin $(10 \mathrm{mg} / \mathrm{ml})$. The number of tyrosyl residues modified was deduced from the loss of tyrosyl residues in the amino acid analyses of the mixtures after modification.

enzyme activity (Figure 4) when compared to the uncomplexed enzyme.

\subsection{Modification of tyrosine residues with TNM}

The effect of TNM on the activity of barley malt $\alpha$-amylase 2 is shown in Table III. In the uncomplexed enzyme 4 tyrosyl residues are

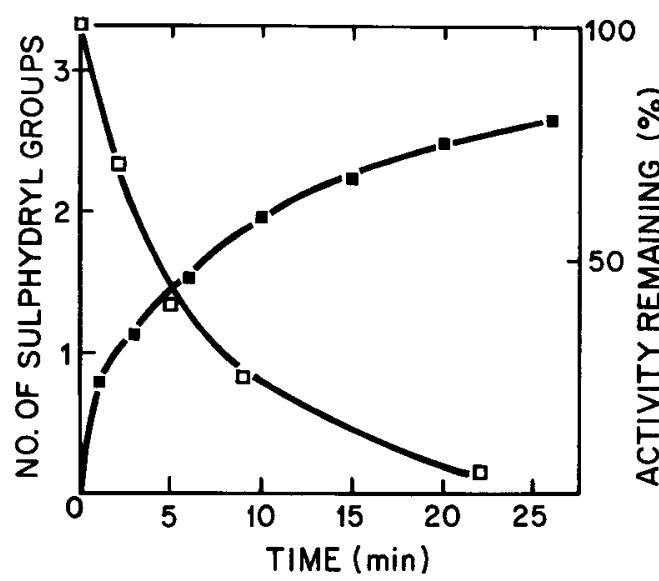

Figure 5. Determination of the free sulphydryl groups in native $\alpha$-amylase 2 . The enzyme was treated as described (2.2.4). The number of sulphydryl groups modified in the enzyme $(33 \mu \mathrm{M})(\mathbf{D})$ is shown as a function of time, as is the activity of the enzyme remaining ( $\square$ ). nitrated under the conditions stated. Nitration in the presence of ligands was also carried out. Aplanin prevents loss of activity and only one tyrosyl residue is nitrated. The other ligands employed, while reducing the number of tyrosyl residues nitrated to 3 , have less effect on the loss of enzyme activity upon nitration compared with aplanin.

\subsection{Determination of sulphydryl groups exposed to solvent}

Figure 5 shows the effect of DTNB on the enzyme in its native state. Between 2 and 3 sulphydryl groups of the three in the protein (deduced from the cDNA sequence (35)) are apparently reactive with DTNB in the native enzyme, suggesting that the enzyme does not contain disulphide bridges. Furthermore, a sulphydryl group(s) appears to be essential for maintenance of a catalytically active enzyme.

\subsection{Difference spectroscopy}

The difference spectra of barley malt $\alpha$-amylase 2 induced by maltose, acarbose, $\beta$-cycloheptaamylose and aplanin are shown in Figure 6. The spectra with both maltose and acarbose display similar characteristics, particularly the trough at 288-290 $\mathrm{nm}$. $\beta$-Cycloheptaamylose, on the other hand, induced spectral changes characterized by peaks at 293 and $284 \mathrm{~nm}$ and a trough at $289 \mathrm{~nm}$. Aplanin also induced 


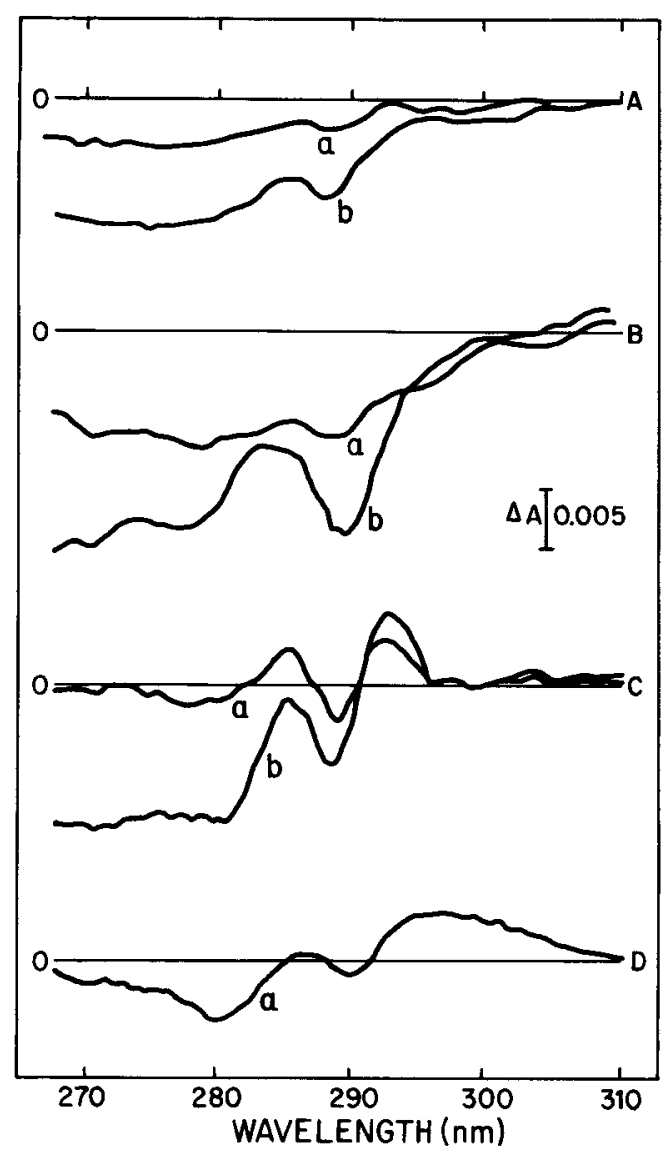

Figure 6. Difference spectra of $\alpha$-amylase 2 complexed with various ligands. Enzyme $(5 \mu \mathrm{M})$ in $10 \mathrm{mM}$-MES and $1 \mathrm{~mm}-\mathrm{CaCl}_{2}, \mathrm{pH} 6.7$, was perturbed with: $\mathrm{A}$. maltose, a. $7.0 \mathrm{~mm}$, b. $13.6 \mathrm{~mm}$; B. acarbose, a. $64 \mu \mathrm{M}$, b. $3.0 \mathrm{~mm}$; C. $\beta$-cycloheptaamylose, a. $0.52 \mathrm{~mm}$, b. 1.3 $\mathrm{mm}$; D. aplanin, a. $0.0015 \% \mathrm{w} / \mathrm{v}$.

spectral changes similar to $\beta$-cycloheptaamylose with an additional broad peak above $290 \mathrm{~nm}$.

The spectra of the complex of $\beta$-cycloheptaamylose and $\alpha$-amylase 2 is consistent with the perturbation of tryptophan indicated by the peak at $293 \mathrm{~nm}(15,16)$. Maltose and acarbose do not appear to perturb tryptophan. The spectral changes induced by these ligands most probably reflect interaction with tyrosyl residues $(15,16)$. Clearly $\beta$-cycloheptaamylose binds to the enzyme in a different mode from maltose and acarbose. Unlike maltose and acarbose aplanin also appears to interact with tryptophan residues and this interaction seems to involve structural changes distinct from those obtained with $\beta$-cycloheptaamylose. This is in agreement with the observations that aplanin can protect the enzyme from various tryptophanyl modifying reagents and, in contrast to $\beta$-cycloheptaamylose, prevent both modification and inactivation.

\subsection{Fluorescence spectroscopy}

The excitation and emission spectra of $\alpha$-amylase 2 have maxima at 280 and $342 \mathrm{~nm}$, respectively. This behaviour is typical of fluorescence produced by tryptophanyl residues (43). Figure 7 shows the effect on the fluorescence spectrum of complexing $\alpha$-amylase 2 with ligands and Table IV shows the values of $K_{\text {diss }}$ as calculated for the various ligands from fluorescence titrations. Aplanin and $\beta$-cycloheptaamylose induce

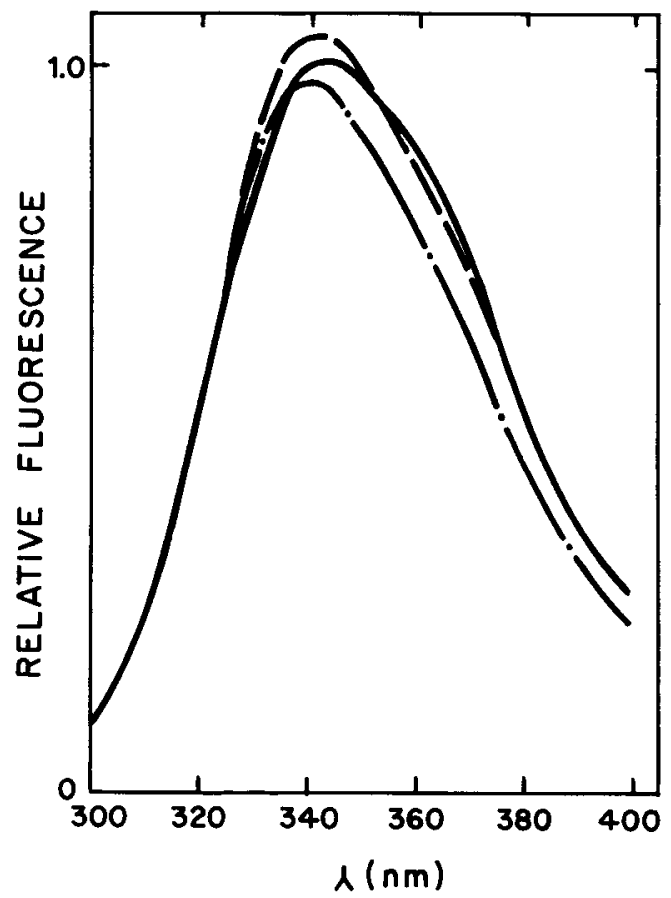

Figure 7. Fluorescence of barley malt $\alpha$-amylase 2 complexes with aplanin and $\beta$-cycloheptaamylose. The fluorescence spectrum of the enzyme $(0.8 \mu \mathrm{M})$ in $1 \mathrm{ml} 50 \mathrm{~mm}-\mathrm{MES}$ and $1 \mathrm{~mm}-\mathrm{CaCl}_{2}, \mathrm{pH} 6.7$, was measured in the absence ( $\longrightarrow$ ) and presence of $(-\rightarrow)$ aplanin $(2.36 \mu \mathrm{g} / \mathrm{ml})$ and $(\rightarrow-) \beta$-cycloheptaamylose $(3.5 \mathrm{~mm})$. 


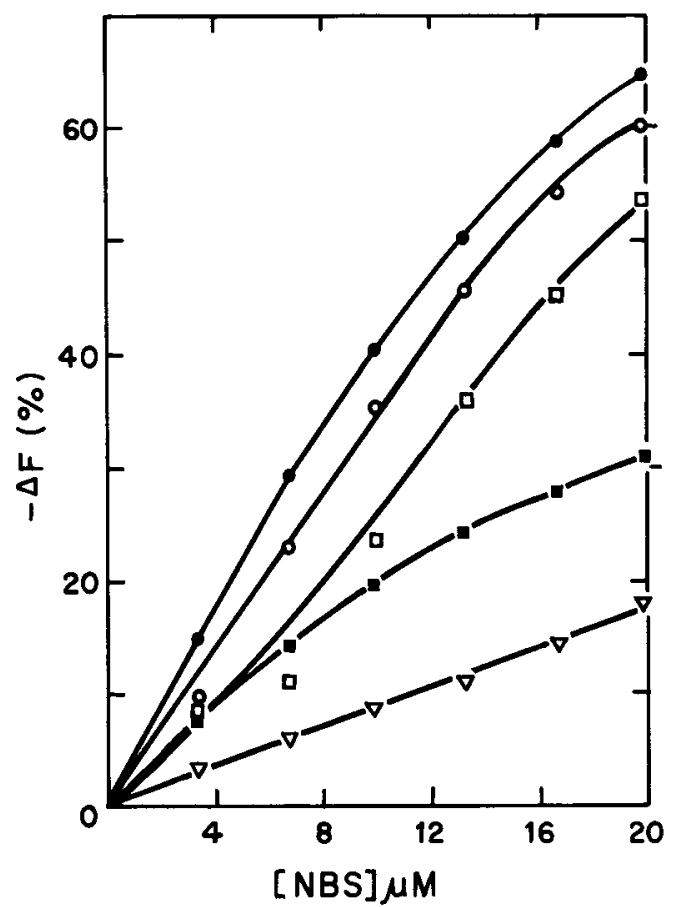

Figure 8. Fluorescence at $342 \mathrm{~nm}$ of $\alpha$-amylase 2-ligand complexes oxidized with NBS. Enzyme $(0.77 \mu \mathrm{M})$ in the absence ( $)$ and presence of ligands in 50 mM-MES and $1 \mathrm{mM}-\mathrm{CaCl}_{2}, \mathrm{pH} 6.7$, was reacted with increasing amounts of NBS and the fluorescence followed in situ. The ligands used were as follows: maltose $(28 \mathrm{~mm})(\mathrm{O})$; acarbose $(0.024 \mathrm{mM})(\square) ; \beta$-cycloheptaamylose $(8.8 \mathrm{mM})(\square)$; aplanin $(10 \mathrm{mg} / \mathrm{ml})(\nabla)$.

a blue shift in the maximum emission spectrum of 2 and $4 \mathrm{~nm}$, respectively, indicative of a change to a more hydrophobic environment of the tryptophans affected $(8,43)$. Aplanin, in addition, causes an increase in the fluorescence intensity which implies a weakening of interactions between the tryptophan(s) affected and neighbouring residues. $\beta$-Cycloheptaamylose addition results in a decrease in fluorescence intensity which could reflect conformational changes that alter the intrinsic quenching of the tryptophan(s) involved (43).

The effect of NBS on the fluorescence of the enzyme in the presence of various ligands is shown in Figure 8. Aplanin prevents loss of enzyme fluorescence to the greatest extent while $\beta$-cycloheptaamylose also has a significant effect on the retention of fluorescence. Results with other ligands investigated do not differ greatly from the behaviour of the uncomplexed enzyme, suggesting that tryptophan residues are equally accessible to the reagent in their presence or absence.

\section{DISCUSSION}

Both tryptophan and tyrosine are involved in the mechanism of action of amylolytic enzymes $(8,18,32)$. Barley malt $\alpha$-amylase 2 contains a high proportion of both tryptophan (16 residues) and tyrosine (15 residues) and our investigations show that 4-6 tryptophanyl and 10-12 tyrosyl residues are exposed to the solvent, thus being available for possible interaction with substrates.

Chemical modification with dimethyl(2-hydroxy-5-nitrobenzyl)sulphonium bromide or tetranitromethane inactivated the enzyme, modifying 4 tryptophanyl and 4 tyrosyl residues, respectively. Further evidence for the involvement of tryptophanyl and tyrosyl residues in $\alpha$-amylase 2 activity arises from the inactivation of the enzyme by oxidation with NBS and iodination, respectively.

Investigation of enzyme inactivation by the above reagents can be expanded using compounds which form complexes with the enzyme similar to that formed between the enzyme and substrate. A range of such ligands were employed in the modification reactions, with varying results. The inhibitor aplanin was effective in

Table IV. Dissociation constants of ligands with $\alpha$ amylase 2, calculated from fluorescence titrations.

\begin{tabular}{lc}
\hline Ligand & $\mathrm{K}_{\text {diss }}$ \\
Maltose & $16.7 \mathrm{mM}$ \\
Acarbose & $5.0 \mu \mathrm{M}$ \\
$\beta$-Cycloheptaamylose & $4.2 \mathrm{mM}$ \\
Aplanin & $1.2 \mu \mathrm{M}^{\mathrm{a}}$ \\
\hline
\end{tabular}

$\mathrm{K}_{\text {diss }}$ values were estimated from plots of $\Delta \mathrm{F}(\%)^{-1}$ vs. [ligand] ${ }^{-}$

a. This represents $20 \%$ of the calculated value as this is the estimated fraction of the mixture which has inhibitory activity. The $\mathrm{K}_{\text {diss }}$ is equal to $2.0 \mu \mathrm{g} / \mathrm{ml}$, assuming an average molecular weight of 1700 for aplanin. 
preventing inactivation by both tryptophanyl and tyrosyl reagents. With the reagent dimethyl(2-hydroxy-5-nitrobenzyl)sulphonium bromide, in addition to its protection of activity, aplanin also prevented the modification of 2 tryptophanyl residues. In the case of tyrosyl residue modification with $\mathrm{TNM}$, this ligand prevented modification of 3 residues as well as preventing enzyme inactivation. These results indicate that as many as 2 accessible tryptophanyl residues and 3 tyrosyl residues may be essential to the functioning of the barley malt $\alpha$-amylase 2 .

$\beta$-Cycloheptaamylose, a cyclodextrin used in the affinity purification of cereal $\alpha$-amylases (45), forms a complex with the enzyme without protection of enzyme activity when exposed to tryptophan and tyrosine modifying reagents. However, there was a reduction in the number of tryptophanyl residues modified by dimethyl(2hydroxy-5-nitrobenzyl)sulphonium bromide at the lower reagent to enzyme ratios, possibly reflecting the interaction of $\beta$-cycloheptaamylose with a non-essential tryptophanyl residue.

In contrast to aplanin, acarbose, a closely related but smaller pseudo-maltooligosaccharide, did not prevent inactivation of the enzyme activity by the modifying reagents. Only a combination of maltose and acarbose to some degree prevented inactivation of the enzyme by NBS and TNM. When acarbose was then combined with maltose and $\beta$-cycloheptaamylose there was no additional protection of tyrosyl residues and the residual activity remained low. In the case of NBS oxidation, combination of ligands did not affect the extent of inactivation significantly, but the addition of $\beta$-cycloheptaamylose decreased the number of tryptophans oxidized in comparison to maltose and acarbose.

The oxidation of sulphydryl groups by NBS may lead to inactivation of the enzyme, as it appears that a sulphydryl group(s) is essential for activity (3.7). However, it is not known if the group(s) oxidized by NBS correspond to the group(s) essential for activity.

Difference spectroscopy was employed to confirm the formation of different types of complexes with the ligands mentioned above. Complexation of the enzyme with $\beta$-cycloheptaamylose and aplanin was characterized by the induction of spectra attributed to the perturbation of tryptophanyl residues, while maltose and acarbose did not display any perturbation of tryptophan(s), showing spectra associated with the perturbation of tyrosyl residue(s). This is in agreement with the dissimilarity between the protective effects of acarbose and aplanin and the protection of tryptophan observed on addition of $\beta$-cycloheptaamylose to a maltose/acarbose/enzyme complex prior to NBS oxidation.

Fluorescence measurements of enzyme complexation with ligands similarly indicate that aplanin and $\beta$-cycloheptaamylose interact with tryptophanyl residue(s). Treatment of complexed enzyme with NBS again demonstrates the protective effect of aplanin and $\beta$-cycloheptaamylose towards tryptophanyl residues while very minor protection is given by acarbose or maltose.

The results presented here represent an initial study of the role of tryptophan and tyrosine in $\alpha$-amylase activity. However, it is possible to make certain proposals as to the nature of their involvement.

$\beta$-Cycloheptaamylose does not inhibit $\alpha$-amylase activity in the Phadebas assay (unpublished results). This fact, in conjunction with the inability of $\beta$-cycloheptaamylose to prevent inactivation of the enzyme activity by chemical modification to any significant extent, suggests that a tryptophan required for the maintenance of enzyme activity does not interact with this ligand. Furthermore, the above observations would also support the proposal that the ligand does not occupy a position in the active site cleft when complexed with the enzyme. This is in agreement with previous proposals of a "surface" site in barley malt $\alpha$-amylase to which $\beta$-cycloheptaamylose binds (45). A tryptophanyl residue is located in the surface site of glycogen phosphorylase $(11,37)$ and similar sites have been demonstrated in porcine pancreatic $\alpha$-amylase $(14,33)$. In $A$. niger glucoamylase G1 oxidation of 2 tryptophanyl residues in the carboxyl terminal region caused selective loss of the ability of this enzyme to adsorb onto raw starch, while the hydrolysis of soluble substrates was not affected (41). Thus it seems that a "surface" site may be a common feature of several carbohydrate binding enzymes whose 
roles require them to form complexes with insoluble polysaccharide material.

Assuming that aplanin forms a complex with the enzyme in a similar manner to acarbose, the different effect of these compounds on the chemical modification of $\alpha$-amylase may be due to the greater chain length of the aplanin molecule. The active site cleft of barley $\alpha$-amylase 2 is thought to contain at least 9 subsites (27). Hence we may assume that aplanin fully occupies the entire carbohydrate binding site, whereas acarbose only binds to 4 subsites. Thus aplanin compared to acarbose protects a far greater proportion of essential residues from chemical modification, which turned out to be crucial for maintenance of catalytic activity.

\section{ACKNOWLEDGEMENTS}

We would like to thank Professor MARTIN OTTESEN for his support of this work and critical review of the manuscript. Ms. SIDSEL EHLERS is thanked for her expert technical assistance and Ms. BODIL CORNELIUSSEN for performing the amino acid analyses. Professor DITER vON WETTSTEIN is thanked for use of the Varian 2200 spectrophotometer and Fil.dr. LARS MUNCK for the use of the Aminco model SPF 500 spectrofluorometer. Drs. E. Truscheit and D. SCHMIDT are thanked for their kind gifts of acarbose and aplanin.

\section{REFERENCES}

1. AZARI, P. R. \& R. E. FEEney: The resistance of conalbumin and its iron complex to physical and chemical treatments. Arch. Biochem. Biophys. 92, 44-52 (1961)

2. Bertoft, E., C. ANDTfolk \& S. -E KulP: Effect of $\mathrm{pH}$, temperature, and calcium ions on barley malt a-amylase isoenzymes. J. Inst. Brew. 90, 298-302 (1984)

3. BRown.A.H.D.\&J.V.JACOBSEN: Genetic basis and natural variation of $\alpha$-amylase isozymes in barley. Genet. Res. Camb. 40, 31 5-324 (1982)

4. Buonocore, V, P Giardina, R. Parlamenti, E PoERIO \& V. SILANO: Characterisation of chicken pancreas $\alpha$-amylase isozymes and interaction with protein inhibitors from wheat kernel. J. Sci. Food Agric. 35, 225-232 (1984)

5. CALlis, J.\& T. .H D. Ho: Multiple molecular forms of the giberellin-induced $\alpha$-amylase from the aleurone layers of barley seeds. Arch. Biochem. Biophys. 224, 224-234 (1983)

6. Chandler, P. M., J.A.ZWAR, J.V.JaCOBSEN, T.J. V. HIGGINS\& A S. INGLIS: The effects of giberellic acid and abscisic acid on $\alpha$-amylase mRNA levels in barley aleurone layers studies using an $\alpha$-amylase cDNA clone. Plant Mol. Biol. 3, 407-418 (1984)

7. Chrispeels. M J. \& J. E. VARner: Giberellic acidenhanced synthesis and release of $\alpha$-amylase and ribonuclease by isolated barley aleurone layers. Plant Physiol. 42, 398-406 (1967)

8. Clarke, A J. \& B. Svensson: The role of tryptophanyl residues in the function of Aspergillus niger glucoamylase G1 and G2. Carlsberg Res. Commun. 49, 111-122 (1984)

9. DuA, R D. \& S. KochHaR: Active site studies on Bacillus amyloliquefaciens $\alpha$-amylase (I). Mol. Cell Biochem. 66, 13-20 (1985)

10. DUA, R. D. \& S. KochHaR: Modification of carboxyl group at the active site of liquefying $\alpha$-amylase. Ind. J. Biochem. Biophys. 22, 289-292 (1985)

11. Fletterick, R. J, J Sygusch, H. Semple \& N B MADSEN: Structure of glycogen phosphorylase a at 3. $0 \AA$ resolution and its ligand binding sites at $6 \AA$. J. Biol. Chem. 251, 6142-6146 (1976)

12. Glazer, A. N., R J. Delange \& D. S. Sigman: Chemical modification of proteins. In: Laboratory techniques in biochemistry and molecular biology, vol. 4, 95-99, (eds. T. S. Work \& E. Work, North-Holland, Amsterdam, 1975)

13. HABEEB, A F.S A.: Reaction of protein sulphydryl groups with Ellman's reagent. Meth. Enzymol. XXV(B), 457-464 (1972)

14. Haser. R., F Payan, M. Pierrot, G Buisson \& E DUEE: Structure tridimensionelle de l'a-amylase pancreatique de porc (resolution $5 \AA$ ). J. Chim. Phys. 76, 823-825 (1979)

15. Herskovits, T. T. \& SR. M Sorensen: Studies of the location of tyrosyl and tryptophyl residues in proteins. I. Solvent perturbation data of model compounds. Biochemistry 7, 2523-2542 (1968)

16. Herskovits, T. T \& SR. M. SorensEn: Studies of the location of tyrosyl and tryptophyl residues in protein. II. Applications of model data to solvent perturbation studies of proteins rich in both tyrosine and tryptophan. Biochemistry 7, 2533-2542 (1968)

17. HORTON, H R. \& W. P. TUCKER: Dimethyl(2-hydroxy-5-nitrobenzyl)sulphonium salts. J. Biol. Chem. 245, 3397-3401 (1970)

18. Hoschke, A., E. Laszlo \& J Hollo: A study of the role of tyrosine groups at the active centre of amylolytic enzymes. Carbohydr. Res. 81, 157-166 (1980) 
19. JACOBSEN.J.V \& T.J.V Higgins: Characterization of the $\alpha$-amylases synthesized by aleurone layers of Himalaya barley in response to giberellic acid. Plant Physiol. 70, 1647-1653 (1982)

20. JaCobsen, J. V., J. G. SCANDalios \& J. E. VARner: Multiple forms of amylase induced by giberellic acid in isolated barley aleurone layers. Plant Physiol. 45, 367-371 (1970)

21. Kita, Y., M. Fukazawa, Y. NitTa \& T. Watanabe: Kinetic study on chemical modification of Takaamylase A. I. Location and role of tryptophan residues. J. Biochem. 92, 653-659 (1982)

22. Kita, Y., S. SaKaguchi, Y. NitTa \& T. Watanabe: Kinetic study on chemical modification of Takaamylase A. II. Ethoxycarbonylation of histidine residues. J. Biochem. 92,1499-1504 (1982)

23. KосннаR, S. \& R. D. DUA: An active centre tryptophan residue in liquefying $\alpha$-amylase from Bacillus amyloliquefaciens. Biochem. Biophys. Res. Commun. 126, 966-973 (1985)

24. LOYTER, A \& M. SCHRAMM: Multimolecular complexes of $\alpha$-amylase with glycogen limit dextrin. J. Biol. Chem. 241, 2611-2617 (1966)

25. MACGregor, A. W: $\alpha$-Amylase I from malted barley - Physical properties and action pattern on amylose. Cereal Chem. 55, 754-765 (1978)

26. MacGregor, A W \& D. L. BallanCE: Hydrolysis of large and small granules from normal and waxy barley cultivars by $\alpha$-amylase from barley malt. Cereal Chem. 57, 397-402 (1980)

27. MacGregor, E. A. \& A. W MacGregor: The action of cereal $\alpha$-amylases on solubilized starch and cereal starch granules. In: New Approaches to Research on Cereal Carbohydrates (eds. R. D. Hill \& L. Munck, Elsevier, Amsterdam, 1985) 149-160

28. Matsuura, Y., M Kusunoki, W Harada \& M KAKUDO: Structure and possible catalytic residues of Taka-amylase A. J. Biochem. 95, 697-702 (1984)

29. Mundy, J., I. Svendsen \& J. HejgaARd: Barley $\alpha$-amylase/subtilisin inhibitor. I. Isolation and characterization. Carlsberg Res. Commun. 48, $81-90$ (1983)

30. NitTa, Y, T. Kunikata \& T. Watanabe: Difference spectroscopic study of the interaction between soybean $\beta$-amylase and substrate or substrate analogues. J. Biochem. 93, 1195-1201 (1983)

31. OHNISHI, M.: Studies of the interaction of substrate analogues with bacterial liquefying $\alpha$-amylase by means of spectrophotometry and steady state kinetics. J. Biochem. 69, 181-189 (1971)

32. OHNISHI, M \& K. HIROMI: Studies on the subsites of amylases. IV. Tryptophan residues of glucoamylase from Rhizopus niveus studied by chemical modification with $\mathrm{N}$-bromosuccinimide. J.
Biochem. 79, 11-16 (1976)

33. Payan, F., R. Haser, M. Pierrot, M. Frey, J. P. Astier, B. ABAdie, E. Duee \& G. Buisson: The three-dimensional structure of $\alpha$-amylase from porcine pancreas at 5 ] resolution - the active site location. Acta. Cryst. B36, 416-421 (1980)

34. Prodanov, E., C. Seigner \& G. Marchis-Mouren: Subsite profile of the active center of porcine pancreatic $\alpha$-amylase. Kinetic studies using maltooligosaccharides as substrates. Biochem. Biophys. Res. Commun. 122, 75-81 (1984)

35. ROGERS, J C.: Two barley $\alpha$-amylase gene families are regulated differently in aleurone cells. J. Biol. Chem. 260, 3731-3738 (1985)

36. Rogers, J. C. \& C. Milliman: Isolation and sequence analysis of a barley $\alpha$-amylase cDNA clone. J. Biol. Chem. 258, 8169-8174 (1983)

37. Sansom, M. S. P., D. I Stuart, K. R. Acharya, J. HaJdu, P J MCLaUghlin \& L. N. Johnson: Glycogen phosphorylase $\mathrm{b}$ - The molecular anatomy of a large regulatory enzyme. J. Mol. Structure 123, 3-25 (1985)

38. Seigner.C... E. Prodanov \& G. Marchis-Mouren: On porcine pancreatic $\alpha$-amylase action: Kinetic evidence for the binding of two maltooligosaccharide molecules (maltose, maltotriose and O-nitrophenylmaltoside) by inhibition studies. Eur. J. Biochem. 148, 161-168 (1985)

39. Silvanovich. M. P. \& R. D Hill: Affinity chromatography of cereal $\alpha$-amylase. Anal. Biochem. 73, 430-433 (1976)

40. SPANDE, T. F. \& B. WITKOP: Determination of the tryptophan content of proteins with N-bromosuccinimide. Meth. Enzymol. XI, 489-506 (1967)

41. SVEnsson, B., A J.Clarke\& I SvendSEN: Influence of acarbose and maltose on the reactivity of individual tryptophanyl residues in glucoamylase from A. niger. Carlsberg Res. Commun. 51, 61-73 (1986)

42. Svensson, B., J Mundy, R M Gibson \& I. SvendSEN: Partial amino acid sequences of $\alpha$-amylase isozymes from barley malt. Carisberg Res. Commun. 50, 15-22 (1985)

43. TEale, F. W. J.: The ultraviolet fluorescence of proteins in neutral solution. Biochem. J. 76, 381388 (1960)

44. UedA, S.: Fungal glucoamylases and raw starch digestion. Trends Biochem. Sci. 6, 89-90 (1981)

45. WESELAKE, R. J. \& R D. Hill: Cycloheptaamylose as an affinity ligand of cereal alpha-amylases. Characteristics and a possible mechanism of interaction. Carbohydr. Res. 108, 153-161 (1982)

46. WeSELAKE, R. J. \& R D. Hill: Inhibition of alphaamylase-catalysed starch granule hydrolysis by cycloheptaamylose. Cereal Chem. 60, 98-101 
R.M GiBSON \& B. SvensSON: Chemical modification of barley $a$-amylase 2

(1983)

47. WINTER, A., K. EK \& U. -B. ANDERSON: Analytical electrofocusing in thin layers of polyacrylamide gels. LKB Application Note 250

Accepted by S O. ANDERSEN 